\title{
A Tale of Two Motives: Endogenous Time Preference, Cash-in-Advance Constraints and Monetary Policy
}

\author{
Eric Kam \\ Department of Economics, Ryerson University, Toronto, Canada \\ Email: erickam@economics.ryerson.ca \\ Received October 10, 2012; revised January 18, 2013; accepted February 18, 2013
}

Copyright (C) 2013 Eric Kam. This is an open access article distributed under the Creative Commons Attribution License, which permits unrestricted use, distribution, and reproduction in any medium, provided the original work is properly cited.

\begin{abstract}
This paper demonstrates the effects of modeling an endogenous rate of time preference and two cash-in-advance constraints. If the constraint is levied on consumption and capital goods, time preference effects are neutral and cashin-advance constraint effects invert the Tobin Effect. If the constraint applies solely to consumption goods, opposing motives are offsetting and monetary policy is super neutral.
\end{abstract}

Keywords: Time Preference; Cash-in-Advance; Tobin Effect

\section{Introduction}

\subsection{The Tobin Effect}

Economists have not yet arrived at any consensus regarding how changes in the monetary growth rate affect the real economy in general and steady state capital in particular. In the modern literature, this debate started with Tobin's [1] extensions of Solow [2] and Swan's [3] one-sector, neoclassical growth models, which assumes money is an asset. Using non-optimizing models, this "Tobin Effect" describes how monetary growth yields inflation, which reduces the relative return on holding real balances so that agents convert assets from real balance holdings to capital. However, recently, optimizing underpinnings of the infinitely-lived, representative agent model have been used to determine the effects of inflation and monetary policy on real variables. With respect to modeling money in the Walrasian model, one seminal approach is Stockman's [4] cash-in-advance constraint models where liquidity constraints are applied to the purchase of consumption and capital goods,or consumption goods alone. The implications of these cash-in-advance constraint models contradict Tobinbut this ambiguity is supported by recent empirical evidence that fails to confirm a stylized relationship between monetary growth and real variables.

The Tobin Effect has largely been forgotten because it tends not to arise in optimizing models. In neoclassical models with competition in production and optimizing agents, the return to capital is determined by its marginal product. The household's Euler equation in turn links the return to capital to the growth rate of consumption. Given fixed preferences and no productivity growth, these conditions hold constant the amount of physical capital and its return. Monetary growth has no effect on real variables because the savings rate is endogenous. Households are not concerned with the amount of savings because decisions rely on the return to investment relative to the intertemporal marginal rate of substitution. Monetary policy has no effect on household Euler equations, consumption or capital.

To overcome this limitation and ensure consistent consumption and savings behavior, Kam [5] models the rate of time preference as an increasing function of real wealth to generate a "Tobin Effect" and steady state stability. However, these results do not depend on the counterintuitive behavior assumptions that call into question the appropriateness of Uzawa's [6] time preference function. Monetary growth generates substitution effects that lower the initial value of real wealth and increase the opportunity cost of holding real balances. The ensuing reduction in steady state real balance holdings decreases the rate of time preference and raises savings, however, this generates time preference wealth effects that reinforce the substitution effect and link the monetary and real sectors. Therefore, the additional savings are converted from real balance holdings into steady state consumption and capital. The new steady state is characterized by saddlepath stability. 


\subsection{Cash-in-Advance Constraints and Endogenous Time Preference}

This paper demonstrates the monetary growth effects of modeling an endogenous rate of time preference and a cash-in-advance constraint on the purchases of consumption and capital goods or consumption goods alone. First, if the cash-in-advance constraint applies to consumption and capital purchases, substitution effects increase the opportunity cost of holding real balances, which raises savings by reducing the level of real balance holdings, real wealth and the rate of time preference. Determining whether the added savings raises or lowers consumption and capital depends on the relative magnitude of opposing effects. The cash-in-advance constraint effect generates an investment tax that converts the added savings into real balance holdings by lowering the production and demand for capital and consumption. However, as the substitution effect decreases the initial level of real wealth, it generates endogenous time preference wealth effects that convert the new savings from real balance holdings to steady state consumption and capital through a Tobin Effect. The cash-in-advance constraint effects dominate an endogenous time preference wealth effect, resulting in a new steady state characterized by lowerconsumption and capital.

Second, if the cash-in-advance constraint is imposed on the purchases of consumption goods, monetary growth raises the opportunity cost of holding real balances and the costs of current consumption. The demand for real balance holdings is residually determined so that substitution effects increase savings and permanent real wealth by decreasing current consumption. However, this generates time preference wealth effects where the rise in the rate of time preference lowers savings and increases the demand for current consumption. When an endogenous rate of time preference is coupled with a cash-in-advance constraint imposed solely on consumption purchases, it creates a contradictory effect on steady state capital and consumption. However, equal magnitudes of the opposing effects generate the accommodating neutrality on permanent real wealth and savings so that monetary growth has no effect on real variables.

A cash-in-advance constraintis generally imposed solely on purchases of consumption goods but not investment goods since a country performing investment internally requires no cash-in-advance. However, in a country with a strong separation of industries involved in producing final goods as opposed to capital goods, monetary models must demarcate if a cash-in-advance constraint is imposed on consumption purchases alone (the purchase of final goods) or the purchase of consumption and investment (capital) goods.

Section 2 demonstrates the monetary growth implica- tions of modeling the rate of time preference as an increasing function of real wealth and cash-in-advance constraints on the consumption and capital purchases and consumption goods alone. An alternative solution is provided in Section 3. The final section is a summary.

\section{Cash-in-Advance Constraints}

\subsection{Cash-in-Advance Constraint on Consumption}

Consider an economy that is characterized by infinitelylived representative agents where the discount factor applied to future streams of utility depend positively on real wealth

$$
\beta(v)=\int_{0}^{t} \theta_{v}\left(a_{v}\right) \mathrm{d} v
$$

where $v$ is a chronological time index and $\theta$ is the rate of time preference, assumed to be an increasing function of real wealth $a$. Representative agents maximize utility

$$
\int_{0}^{\infty} u\left(c_{t}\right) \mathrm{e}^{-\beta(v)} \mathrm{d} t
$$

where $c$ is consumption, $u_{c}>0$ and $u_{c c}<0$.

Two flow budget constraints describe the evolution and composition of real wealth

$$
\begin{gathered}
\dot{a}_{t}=f\left(k_{t}\right)+x-c_{t}-\pi_{t} m_{t} \\
a_{t}=k_{t}+m_{t}
\end{gathered}
$$

and there is one stock budget constraint

$$
\lim _{t \rightarrow \infty} a_{t} \mathrm{e}^{-\int_{0}^{t} r_{\mathrm{d}} \mathrm{d} v} \geq 0
$$

where $f$ is a constant returns to scale production function, $x$ is the value of public sector transfers to hold real balances constant following inflation, $k$ is the capital stock, $r$ is the real interest rate, $\pi$ is the inflation rate and $m$ is the level of real balances.

Stockman uses a cash-in-advance constraint levied strictly on consumption purchases, for instance on a country with internal investment, which in continuous time becomes

$$
c_{t} \leq m_{t}
$$

Real balances do not yield utility directly, which implies that the nominal interest rate is positive and (6) and (19) holds with equality. Substituting (6) and (4) into (3) obtains

$$
\dot{a}_{t}=f\left(a_{t}-c_{t}\right)+x-c_{t}\left(1+\pi_{t}\right)
$$

Maximize (2) subject to (5) and (7) using (1) to get the first-order optimality conditions 


$$
\begin{gathered}
u_{c}(c)-\xi\left(f^{\prime}(a-c)+(1+\pi)\right)=0 \\
\xi \theta(k+c)-\xi f^{\prime}(a-c)=\dot{\xi} \\
\lim _{t \rightarrow \infty} a_{t} \xi_{t} \mathrm{e}^{-\int \theta_{v} \mathrm{~d} v}
\end{gathered}
$$

where $\xi$ is the co-state variable. In the steady state, from (9) with $\dot{\xi}=0$

$$
\theta(k+c)=f^{\prime}(a-c)
$$

The resource constraint is given by

$$
\dot{k}=f(k)-c
$$

From (12) with $\dot{k}=0$

$$
c=f(k)
$$

From (3) and (13) with $\dot{a}=0$

$$
\pi^{*}=\mu
$$

Linearizing (8), (11) and (13) using (14) around the steady state level of consumption and capital $\left(c^{*}, k^{*}\right)$ obtains

$$
\left[\begin{array}{ccc}
u_{c c} & -\xi f^{\prime \prime} & -\alpha \\
\theta^{\prime} & \varphi & 0 \\
-1 & f^{\prime} & 0
\end{array}\right]\left[\begin{array}{c}
\mathrm{d} c^{*} \\
\mathrm{~d} k^{*} \\
\mathrm{~d} \xi
\end{array}\right]=\left[\begin{array}{l}
\xi \\
0 \\
0
\end{array}\right] \mathrm{d} \mu
$$

where $\varphi=f^{\prime}+1+\mu>0$. The determinant of the coefficient matrix in (15) is

$$
|\Psi|=-\alpha\left(\theta^{\prime} f^{\prime}+\phi\right)<0
$$

and the effect of monetary growth on steady state capital and consumption is

$$
\frac{\mathrm{d} k^{*}}{\mathrm{~d} \mu}=\frac{\mathrm{d} c^{*}}{\mathrm{~d} \mu}=\frac{0}{|\Psi|}
$$

Monetary growth increases the real costs of consumption and the opportunity costs of holding real balances. As the demand for money is residually determined, the substitution effect lowers the demand for consumption goods and raises the initial levels of permanent real wealth and savings. However, the increase in the initial level of real wealth generates time preference wealth effects that lower savings and the demand for consumption goods. Thus, combining a cash-in-advance constraint imposed strictly on consumption purchases and an endogenous rate of time preference generates a contradictory effect on steady state capital and consumption. However, it is an equal magnitude of the two effects that creates neutrality on permanent real wealth and saving so monetary growth is super neutral.

\subsection{Cash-in-Advance Constraint on Consumption and Investment}

Stockman modeled a second cash-in-advance constraint imposed on consumption and capital purchases (capital and final goods), which in continuous time becomes

$$
m_{t} \geq c_{t}+\dot{k}_{t}
$$

Substituting (18) into (12) and (3) yields two flow budget constraints

$$
\begin{gathered}
\dot{k}_{t}=\left(a_{t}-k_{t}\right)-c_{t} \\
\dot{a}_{t}=f\left(k_{t}\right)+x-c_{t}-\pi_{t}\left(a_{t}-k_{t}\right)
\end{gathered}
$$

The two stock budget constraints are given by (5) and

$$
\lim _{t \rightarrow \infty} k_{t} \mathrm{e}^{-\int^{t} r_{v} \mathrm{~d} v} \geq 0
$$

Maximize (2) subject to (19), (20), (21) and (5) to obtain the first order conditions

$$
\begin{gathered}
u_{c}(c)-(\psi+\rho)=0 \\
\rho \theta(k+m)-\psi\left(f^{\prime}(k)+\pi\right)+\rho=\dot{\rho} \\
\psi \theta(k+m)+\psi \pi-\rho=\dot{\psi} \\
\lim _{t \rightarrow \infty} k_{t} \rho_{t} \mathrm{e}^{-\int^{t} \theta_{v} \mathrm{~d} v}=0 \\
\lim _{t \rightarrow \infty} a_{t} \psi_{t} \mathrm{e}^{-\int \theta^{0} \mathrm{~d} v}=0
\end{gathered}
$$

where $\rho$ and $\psi$ are co-state variables. In the steady state, from (23) with $\dot{\rho}=0$

$$
\rho \theta(k+m)-\psi\left(f^{\prime}(k)+\pi\right)+\rho=0
$$

From (24) with $\dot{\psi}=0$

$$
\psi \theta(k+m)+\psi \pi-\rho=0
$$

From (12) and (19) with $\dot{k}=0$

$$
c^{*}=m^{*}
$$

Linearizing (13), (22), (27), (28) and (29) around $\left(c^{*}, m^{*}, k^{*}\right)$ using (13) obtains

$$
\left[\begin{array}{ccccc}
u_{c c} & 0 & 0 & -1 & -1 \\
0 & \sigma & \rho \theta^{\prime} & (1+\theta) & -\left(f^{\prime}+\mu\right) \\
0 & \psi \theta^{\prime} & \psi \theta^{\prime} & -1 & (\theta+\mu) \\
-1 & f^{\prime} & 0 & 0 & 0 \\
-1 & 0 & 1 & 0 & 0
\end{array}\right]\left[\begin{array}{c}
\mathrm{d} c^{*} \\
\mathrm{~d} k^{*} \\
\mathrm{~d} m^{*} \\
\mathrm{~d} \rho \\
\mathrm{d} \psi
\end{array}\right]=\left[\begin{array}{c}
0 \\
\psi \\
-\psi \\
0 \\
0
\end{array}\right] \mathrm{d} \mu
$$

where $\sigma=\theta^{\prime} \rho-f^{\prime \prime} \psi>0$. The determinant of the coefficient matrix in (30) is 


$$
\begin{aligned}
& |\Phi|=\left(\sigma(\theta+\mu)+\psi \theta^{\prime}\left(f^{\prime}+\mu\right)\right)+\left(\sigma+\psi \theta^{\prime}(1+\theta)\right) \\
& +f^{\prime}\left(\rho \theta^{\prime}(\theta+\mu)+\psi \theta\left(f^{\prime}+\mu\right)+\rho \theta^{\prime}+\psi \theta^{\prime}(1+\theta)\right)>0
\end{aligned}
$$

The effect of monetary growth is determined for capital and consumption

$$
\begin{aligned}
& \frac{\mathrm{d} k^{*}}{\mathrm{~d} \mu}=\frac{-\psi\left(f^{\prime}\right)}{|\Phi|}<0 \\
& \frac{\mathrm{d} c^{*}}{\mathrm{~d} \mu}=\frac{-\psi\left(f^{\prime}\right)^{2}}{|\Phi|}<0
\end{aligned}
$$

Substitution effects increase the opportunity cost of holding real balances and savings while decreasing the initial level of real wealth, real balance holdings and the rate of time preference. Determining whether the additional savings raises or lowers consumption and capital relies on the relative magnitude of two opposing effects. First, the cash-in-advance constraint functions as an investment tax that directs the additional savings away from the production and demand for steady state consumption and capital. However, the decline in real wealth generates endogenous time preference wealth effects that convert new savings from real balance holdings into capital and consumption through a Tobin Effect. As cash-in-advance constraint effects control endogenous time preference wealth effects, inflation lowers capital and consumption. Combine (13) and (6) or (18) and (6) to get

$$
f\left(k^{*}\right)=c=m
$$

Substituting (33) into (1) using (4) yields

$$
\beta(v)=\int_{0}^{t} \theta_{v}\left(k_{v}+f\left(k_{v}\right)\right) \mathrm{d} v
$$

Comparing (1) and (35) demonstrates that the rate of time preference, first modeled as an increasing function of real wealth is transformed into a function that depends solely on capital. As the rate of time preference is no longer an increasing function of real wealth, it no longer generates time preference wealth effects. Therefore, in terms of the first model, substitution effects raise savings and the cash-in-advance constraint acts independently to generate superneutrality. With respect to the second model, inflation yields an investment tax that lowers the effective return and demand for investment goods. Substitution effects again raise savings but the cash-in-advance constraint redirects new saving away from the accumulation of steady state consumption and capital.

\section{Conclusion}

This paper contrasts the varying effects that the same monetary policy can have on steady state capital and consumption using an infinitely-lived representative agent model with an endogenous rate of time preference that depends positively on real wealth. The effect that monetary growth has on real variables depends on the relative magnitude of contradictory effects. First, when the cashin-advance constraint is imposed on capital and consumption purchases, the cash-in-advance constraint effect dominates time preference wealth effects so that monetary growth reverses the Tobin Effect and lowers the steady state demand for capital and consumption goods. However, if the constraint applies strictly to purchases of consumption goods, the same two contradictory effects are of equal magnitude. The cash-in-advance constraint effect is strengthened so inflation is super neutral.

\section{REFERENCES}

[1] J. Tobin, "Money and Economic Growth," Econometrica, Vol. 33, No. 4, 1965, pp. 671-684. doi:10.2307/1910352

[2] R. Solow, "A Contribution to the Theory of Economic Growth," Quarterly Journal of Economics, Vol. 70, No. 1, 1956, pp. 65-94. doi:10.2307/1884513

[3] T. Swan, "Economic Growth and Capital Accumulation," Economic Records, Vol. 32, No. 2, 1956, pp. 334-361. doi:10.1111/j.1475-4932.1956.tb00434.x

[4] A. Stockman, "Anticipated Inflation and the Capital Stock in a Cash-In-Advance Economy," Journal of Monetary Economics, Vol. 8, No. 3, 1981, pp. 387-393. doi:10.1016/0304-3932(81)90018-0

[5] E. Kam, "A Note on time Preference and the Tobin Effect," Economics Letters, Vol. 89, No. 1, 2005, pp. 127 132. doi:10.1016/j.econlet.2005.05.021

[6] H. Uzawa, "Time Preference, the Consumption Function, and Optimal Asset Holdings," In: J. Wolfe, Ed., Value, Capital and Growth: Papers in Honour of Sir John Hicks, Aldine Publishing Company, Chicago, 1968, pp. 485-505. 